\title{
KNOWLEDGE OF HAND WASHING AND FOOD HANDLING PRACTICES OF THE STREET FOOD VENDORS OF AGARTALA, A NORTH EASTERN CITY OF INDIA.
}

Taranga Reang ${ }^{1}$, Himadri Bhattacharjya ${ }^{2}$

\section{HOW TO CITE THIS ARTICLE:}

Taranga Reang, Himadri Bhattacharjya. "Knowledge of hand washing and food handling practices of the street food vendors of Agartal a, a north eastern city of India". Journal of Evolution of Medical and Dental Sciences 2013; Vol. 2, Issue 43, October 28; Page: 8318-8323.

ABSTRACT: OBJECTIVES: To assess the knowledge of hand washing and food handling practices of the street food vendors. STUDY DESIGN: Community based cross-sectional study conducted in Agartala municipal area. METHODS: Structured interview schedule was administered to 234 street food vendors selected by probability proportionate to size sampling technique during 1 st July to $31^{\text {st }}$ August 2011. Microsoft Excel and Epi-info version-6 were used for data entry and analysis and $\mathrm{p} \leq$ 0.05 was considered significant. RESULTS: One hundred and seventeen vendors (50\%) were aged between 30 - 40 years and $98.29 \%$ were males. Forty eight (20.5\%) vendors were illiterate and $40.2 \%$ vendors were from rural areas. One hundred and five vendors (44.9\%) with primary and 78 (32.1\%) with secondary level education knew that unclean hands and dishes can transmit diseases while serving roadside foods. $58.3 \%, 61.9 \%$, and $69.23 \%$ of the vendors were illiterate, primary and secondary educated respectively. Majority of them were not using soap for washing hands. 87.5\%, $58.09 \%, 74.3 \%$ and $50 \%$ of the illiterate, primary educated, secondary educated, and senior secondary educated vendors did not use detergent for washing dishes before and after each serving. One hundred and sixty five (70.5\%) vendors stored unsold food for the next day, while $29.1 \%$ of the vendors discarded the left-over food. CONCLUSIONS: Basic food safety knowledge and practice of hygiene and sanitation by the street food vendors was found to be inadequate. Issuing of food license to them should be subjected to fulfillment the above conditions or they should be trained regarding safe food handling.

KEY WORDS: Street-food-vendor, Hand-washing, Food-handling-practice, Agartala.

INTRODUCTION: The term "street food" refers to a wide variety of ready-to-eat foods and beverages sold and sometimes prepared, in public places. Street food may be consumed where it is purchased or can be taken away and eaten else-where. [1]

Food borne illnesses are a widespread public health problem globally. Developing countries bear the brunt of the problem due to the presence of a wide range of street foods. The established food safety knowledge among the surveyed street food vendors regarding food contamination, types and symptoms of food borne diseases was significant since several pathogenic micro-organisms had also been isolated from many street vended foods. [2]

Trend of eating away from home and the use of partly or fully cooked food is on the rise. Most of the vendors who sold both raw and cooked food items were not regulated. They operated haphazardly without any monitoring of what they prepared and how they prepared it. [3]

Recent years have seen a reversal in this trend but foodpoisoning remains a high priority for the public and government. [4] 
During the months of November and December 2010 a high incidence of Hepatitis A \& gastroenteritis was recorded among the city dwellers of Agartala. The teenagers, young adults \& some newly married couples who are very much fond of fast foods were mainly affected. In this context it was planned to study the knowledge of hand washing \& food handling practices of the street food vendors of Agartala, the capital of Tripura, a North Eastern state of India in order to formulate recommendations for prevention of food borne diseases among the consumers of the street food.

METHODS: The present study was conducted among 234 Street food vendors of Agartala, the capital city of Tripura State, India, during 1st July to 31st August 2011. Minimum sample size requirement for this study at $95 \%$ confidence, using $20 \%$ allowable error and considering the level of awareness of the street food vendors regarding food safety as 30\%[5] was 236 including additional 5\% to compensate for non-response.

The study vendors were selected from different wards of Agartala Municipal area. At first ward wise number of registered food vendors for total 35 wards was obtained from the office of the Food Inspector, Agartala Municipal Council. Then out of these 35 wards, 30 clusters were chosen by probability proportionate to size sampling. Finally 8 (Rounded) vendors were chosen from each of these 30 selected clusters by simple random sampling. Out of 240 selected food vendors, 2 refused to participate in this study, 4 were aged less than 18 years and were excluded. Thus the study sample came down to be 234. Informed verbal consent was obtained from these vendors and data were collected by conducting face to face interview taking 20 minutes equal time for everyone and maintaining confidentiality.

Information thus collected was recorded in a pretested interview schedule. Data were entered in computer and analyzed using Microsoft Excel 2007 and Epi-info version 6.0. P value of 0.05 or less was considered to be significant.

RESULT: Response rate was $97.5 \%$ and $50 \%$ of the respondents were aged between 30 to 40 years, $34.6 \%$ were aged $>40$ years, $10.3 \%$ were aged between 20 to $<30$ years and $5.1 \%$ were aged 18 to 20 years. $98.29 \%$ vendors were males and 59.8\% came from urban areas. $20.5 \%$ of the vendors were illiterate, $44.9 \%$ had primary and $33.3 \%$ secondary level of education. $88.9 \%$ of the food vendors were earning between Rs. 5000 to 10000 per month and $11.1 \%$ had an income between Rs. 1000 to less than 5000 per month. $54.7 \%$ of the vendors were using pipe water, supplied by the municipality while $36.3 \%$ and $8.5 \%$ were using water from tube wells and ponds respectively for preparing food \& washing the dishes. This practice was commoner $(65.0 \%)$ among the urban food vendors $(p=0.000) .32 .1 \%$ and $44.9 \%$ of the vendors with primary and secondary level of education respectively knew that unclean hands and dishes can transmit diseases while serving roadside foods. $85.5 \%$ of the vendors were using low quality or unbranded oils and only $14.5 \%$ were using good quality branded oils for preparing food. $71.4 \%$ of the vendors laid more emphasis on taste, $20.9 \%$ were interested in maintaining the quality of food and $7.7 \%$ could not express their view clearly in this regard.

$42.3 \%$ of the vendors opined that it is difficult for an ordinary road side food vendor to provide cent percent quality, hygienic \& nutritious food. On the other hand $49.6 \%$ vendors had different view while $8.1 \%$ could not express their view regarding this. It was found that 96 vendors 
(41.0\%) were washing dishes before serving the foods whereas 132 (56.4\%) vendors did not practice so. Majority (97.4\% \& 69.5\%) of the secondary \& primary educated vendors respectively washed dishes after serving food $(\mathrm{P}=0.000)$. The vendors with secondary level of education put more emphasis on the quality of food compared to the illiterate vendors $(24.35 \% \mathrm{vs} .10 .4 \%$, $\mathrm{P}=0.024)$.

\begin{tabular}{|c|c|c|c|}
\hline Literacy status & \multicolumn{2}{|c|}{ Whether hand washing is necessary } & P value \\
\hline & Yes, n (\%) & No, n (\%) & \multirow{4}{*}{0.008} \\
\hline Illiterate & $20(29.41)$ & $48(70.59)$ & \\
\hline Primary educated & $21(20.00)$ & $84(80.00)$ & \\
\hline Secondary educated and above & $37(45.68)$ & $44(54.32)$ & \\
\hline
\end{tabular}

Table 1 shows that knowledge regarding hand washing was significantly higher among food vendors, who studied up to secondary level or more $(p=0.008)$.

Table 2. Usage of soap for hand washing by literacy of the street food vendors.

\begin{tabular}{|l|c|c|c|}
\hline \multicolumn{1}{|c|}{ Literacy status } & \multicolumn{2}{|c|}{ Using soap for washing hands } & \multirow{2}{*}{ P value } \\
\hline & Yes, $\mathrm{n}(\%)$ & No, $\mathrm{n}(\%)$ & \multirow{2}{*}{0.000} \\
\cline { 1 - 3 } Illiterate & $20(41.60)$ & $28(58.40)$ & \\
\cline { 1 - 3 } Primary educated & $40(38.10)$ & $65(61.9)$ & \\
\cline { 1 - 3 } Secondary education & $26(30.77)$ & $55(69.23)$ & \\
\cline { 1 - 2 }
\end{tabular}

Table 2 shows that usage of soap for washing hands was the highest among illiterate food vendors and it was found to be significant $(p=0.000)$.

\section{Table 3. Usage of detergent for washing dishes by literacy of the street food vendors.}

\begin{tabular}{|l|c|c|c|}
\hline \multicolumn{1}{|c|}{ Literacy } & \multicolumn{2}{c|}{ Use of detergents } & \multirow{2}{*}{ P value } \\
\hline & Yes, n (\%) & No, n (\%) & \multirow{2}{*}{0.009} \\
\cline { 1 - 3 } Illiterate & $4(8.3)$ & $44(87.5)$ & \\
\cline { 1 - 3 } Primary education & $42(40)$ & $63(58.09)$ & \\
\hline Secondary education & $21(25.6)$ & $60(74.3)$ & \\
\hline
\end{tabular}

Table 3 shows that highest number of illiterate food vendors were not using detergents for washing the dishes and it was found to be significant ( $p=0.009)$.

DISCUSSION: The present study revealed the basic food safety knowledge and practices of hygiene among the street food vendors of Agartala city. Out of 234 food vendors who participated in this study, about half of them were aged between 30 - 40 years and Patience Mensah et al, 2002 [6] also reported almost similar finding in a study conducted in Accra city,Ghana. In this study 98.29\% were males and $1.71 \%$ were females and this finding was in agreement with Muinde OK et al, 2005. 17] Comfort O. Chukuezi, 2010 [8] at Owerri, Nigeria, reported that $66.67 \%$ of the vendors were women and majority of them belonged to 31 to 40 years age group. Most of the vendors were either illiterate $(20.5 \%)$ or had education up to primary level (44.9\%). 
This result was in agreement with Comfort O. Chukuezi, 2010 [8] and M.A. Abdalla et al, 2008 [9]. In this study, it has been found that despite having minimum level of education \& food safety knowledge many of the food vendors did not follow food safety practice \& personal hygiene strictly. This might be due to lack of adequate time, money and non availability of water and space. Idowa OA et al, 2003 [10] reported that only few vendors (12\%) acquired the knowledge of food preparation by formal training. Only $31 \%$ of the vendors had the annual medical health certificate to indicate that they have carried out the recommended physical and medical examination. Sixty five percent of urban and 39.36\% of the rural food vendors in Agartala used tap water for preparing food but they did not have access to running water all the time. They collected water from roadside tap or mobile tankers which was then stored for later use in a container. The same water was used for cooking food, washing hands and dishes. Hand washing was found difficult due to lack of running water at the vending site.

The same was found by M.A. Abdalla et al, 2008. [9] Neela Badrie et al, 2003 [11] reported that only $10 \%$ of the vendors had access to running water, electricity and sanitation. $55 \%$ of them brought their supply of water in buckets, water containers or coolers from home or collected water from a near-by-public stand-pipe. [11] Patient Mensah et al, 2002 [6] reported that only 10 (8.5\%) vendors had access to clean running water. Shinkre Rajal et al, 2007 [5] reported that for $>95 \%$ of the vendors, water had been a major problem. Almost all of them used tap water for preparing food and eighty eight percent of the vendors kept packaged drinking water for sale. Majority of the street food vendors, in spite of attaining either primary or secondary level of education, did not know the necessity of hand washing before serving foods ( $\mathrm{P}=0.008)$.

Keeping the preparation surface dirty and use of low quality locally packed oil by $85.5 \%$ of the vendors for preparation of food was comparable with that of Comfort O. Chukuezi, 2010 [8] at Owerri, Nigeria and Murat bas et al, 2004. [12] Shinkre Rajal et al, 2007 [5] reported that around $30 \%$ of the food vendors consider food safety and brand at the time of procurement. Majority of the illiterate, primary and secondary educated food vendors did not use soap for hand washing before serving food to the customers $(\mathrm{p}=0.000)$. Almost similar findings were reported by Murat bas et al, 2004. [12] Shinkre Rajal et al, 2007 [5] reported that 65\% of the 7 vendors were using soap for hand washing. It was found that 96 vendors $(41.0 \%)$ were practicing washing of dishes before serving food whereas 132 (56.4\%) vendors did not.

Shinkre Rajal et al, 2007[5] also reported that $61 \%$ of the vendors were practicing dish washing before serving food, $60 \%$ vendors used disposable vessels for serving food and 58\% kept the foodstuff covered at the vending sites. In the present study very few vendors were found to use detergents for washing the dishes, whereas Muinde OK et al, 2005[7] and Shinkre Rajal et al, $2007^{[5]}$ reported that majority of the vendors were using detergents for washing dishes after each use. In the present study, majority of the vendors were found to store the unsold food for next day and only $29.1 \%$ of them used to discarded the unsold food. It was in agreement with Muinde OK et al, 2005. [7] Comfort O. Chukuezi, 2010[8] at Owerri, Nigeria reported that $9.52 \%$ of the vendors used to display food items openly in the stalls for serving while $23.81 \%$ vendors stored them in the wheelbarrows. Nearly forty three percent (42.86\%) kept the leftovers with poor storage facilities for serving on the next day and most of them were stored in covered warmers or utensils whereas Shinkre Rajal et al, $2007[5]$ reported that leftover food items were found to be stored under refrigeration by $63 \%$ of the 
food vendors. The overall knowledge of the food vendors regarding food safety was found to be very poor.

Out of 234 street food vendors of Agartala city only $32.1 \%$ with primary, $44.9 \%$ with secondary level of education knew that unclean hand and dishes can transmit diseases while serving roadside foods and was comparable with the findings of Murat bas et al, 2004 [12] and M.A. Abdalla et al, 2008.[9] Literacy was supposed to have positive impact up on this issue but surprisingly it was seen that even many of the literate vendors were also unaware of food safety practices.

CONCLUSION: The present study demonstrated that street food vendors in Agartala city, of Tripura state followed very minimal hygienic and sanitary practices. Poor socioeconomic status and lack of awareness may be the limiting factors towards observance of safe food handling practices. Authority may issue licenses to the street food vendors after they fulfill some of the basic and essential food safety and hygienic measures. Periodic training of the vendors regarding safe food handling may help in improving the situation. The provision of basic sanitation, water supply and waste management are recommended to minimize the gap between knowledge and practice of safe street food vending.

ACKNOWLEDGEMENT AND DECLARATION: We declare that no competing interest exists. The study did not receive funding from any agency. Institutional Ethics Committee of Agartala Government Medical College has approved the study.

\section{REFERENCE:}

1. WHO. Essential safety requirements for street vended foods. Food Safety Unit, Division of Food and Nutrition 1996; WHO/FNU/FOS/96.7.

2. Omemu AM, Edema MO and Bankole MO. Bacteriological assessment of street vended ready to eat (RTE) vegetables and pre-packed salad in Nigeria, Nig. J. Microbiol 2005; 19(1- 2): 497504.

3. Tivadar B. Save money, waste love, ambivalence toward purchased convenience food. Annals, series Historia et Sociologia 2003; 13(1): 87-102.

4. Umoh VJ, Odoba MB. Safety and quality evaluation of street foods sold in Zaria, Nigeria, Food Control 1999; 10: 9-14.

5. http://www.iiml.ac.in/events/C2_02_Shinkre_R.pdf (accessed on 16-06-2011)

6. Patience Mensah, Dorothy Yeboah-Manu, Kwaku Owusu-Darko and Anthony Ablordey. Street foods in Accra, Ghana: how safe are they? Bulletin of the World Health Organization 2002; 80(7):546-554. 9

7. Muinde OK, Kuria E. Hygienic and sanitary practices of vendors of street foods in Nairobi, Kenya. African Journal of Food Agriculture and Nutritional Development (AJFAND) 2005; 5(1).

8. Comfort O. Chukuezi. Food Safety and Hygienic Practices of Street Food Vendors in Owerri, Nigeria (2010) at Owerri, Nigeria. Studies in Sociology of Science 2010; 1(1): 50-57.

9. M.A. Abdalla, S.E. Suliman and A.O. Bakhiet. Food safety knowledge and practice of street food vendors in Atbara city (Naheer Elneel State Sudan). African Journal of Biotechnology 2009; 8(24): 6967- 6971. 
10. Idowa OA, Rowland SA. Oral fecal parasites and personal hygiene of food handlers in Abeokuta, Nigeria. Afr. Health Sci.2006; 6(3): 160-164.

11. Neela Badrie, Andrew Joseph, Allyson Chen. An observational study of food safety practices by street vendors and microbiological quality of street-purchased hamburger beef patties in Trinidad, West Indies. Internet Journal of Food Safety 2003; 3: 25-31.

12. Murat Bas, Azmi Safak Erush, Gokhan Kivance. The evaluation of food hygiene, knowledge, attitude and practices of food handlers in food business in Turkey. Food Control 2006; 17:317322.10.

\section{AUTHORS:}

1. Taranga Reang

2. Himadri Bhattacharjya

\section{PARTICULARS OF CONTRIBUTORS:}

1. Assistant Professor, Department of Community Medicine, Agartala Government Medical College.

2. Assistant Professor, Department of Community Medicine, Agartala Government Medical College.

\section{NAME ADDRESS EMAIL ID OF THE CORRESPONDING AUTHOR:}

Dr. Himadri B hattacharjy a,

Assistant Professor, Departm ent of Co mmunity Medicine, Agartala Government Medical College, P.O. Kunjavan, PIN - 799006.

Tripura, India,

Email - hbhattacharjya@ rediffmail.com

Date of Submission: 14/10/2013. Date of Peer Review: 15/10/2013. Date of Acceptance: 21/10/2013. Date of Publishing: 24/10/2013 